\title{
The Future Reform and Optimization of Insider Trading Law in China
}

\author{
Jie Xie \\ Associate Professor, Koguan Law School \\ Shanghai Jiao Tong University
}

\begin{abstract}
The purpose of this article is to analyze the legal theory and complex practical issues related to the anti-insider trading legal framework. Comparative methodology is utilized to explore reas onable routes to optimize the Chinese insider trading law through integrating some developed rules established in US into the reality of Chinese practice. A more systematic mechanism of private, administrative and criminal action of insider trading cases should be constructed in China. This article provides a better understanding about the ongoing developments of Chinese capital market and the real pictures of regulatory practice in China to the world investors who try to find the investment or speculation opportunities in the emerging financial markets.
\end{abstract} law

Keywords-insider trading; China; legal reform; comparative

\section{INTRODUCTION}

It is necessary to analyze the legal theory and complex practical issues related to the anti-insider trading legal framework in a more intensive way, and find reasonable routes to optimize the Chinese insider trading law through integrating some developed rules established in US into the reality of Chinese practice. Not only can it help the legal practitioners correctly apply the legal rules in insider trading cases, but the essence of insider trading can also be fully investigated in the framework of legal theory. In the process of explaining the legal theory underlying insider trading and the practical routes to optimize the relevant judicial rules of insider trading in China, the US capital market can have a better understanding about the ongoing developments of Chinese capital market and the real pictures of regulatory practice in China while trying to find the investment or speculation opportunities in the emerging financial markets.

\section{Restructure of the Principle of Anti-Insider Trading REGIME}

The most efficient orientation of securities regulation is to punish and deter insider trading which destroys the foundation of financial markets or cause extremely massive economic losses of retailer investors, rather than tightly control the intensifying information competition among the sophisticated market participants.

\section{A. Private Control Pattern Protected by the Regulatory Framework}

Enhanced regulatory framework is the protective mechanism of capital markets but the speculative financial trades should be determined by capital markets and the excessive insider trading schemes which infringe investor rights and market information competition mechanism should be regulated by civil law regimes or self-restored by the competitive mechanism. Therefore the control rules will be mainly enforced in a privatized legal environment. The intensifying competition mechanisms of both capital markets and private legal service markets should be internalized to efficiently control most of insider trading. And this highly marketed control model should be protected but not disrupted by the intervention of the capital market regulatory regime.

The administrative or criminal liability of insider trading is triggered only when the legal competition between the actors of insider trading and investors who claim harmed by insider trading cannot heal the damages of the financial market caused by the alleged insider trading.[1] It should be emphasized that the administrative or criminal proceeding against insider trading need to be carried out with low cost, which means the CSRC shall construct a whistleblower program just US for encouraging the public to provide original information about suspected insider trading regime.

A systematic mechanism of private action of insider trading cases should be constructed in China, especially the right of initiating class action, which will give the real protection to the investors who may be harmed by insider trading. Apparently the premise of this marketed control pattern should be constructed on a relatively perfect civil liability regime with clear and practical definition, constitution and legal rules on determination of insider trading, most of which may directly or potentially influenced by US insider trading law.

\section{B. Diversified Liability Pattern based on the Risk underlying the Suspected Trading}

It is an objective inequality of information which is one of the sources that causes and continues to maintain the market disparity.[2] This information inequality should be allowed or even upheld, otherwise, the capital market function of optimizing resource allocation will be fundamentally impeded. There is no need to emphasis this gap on the ability to acquire and analyze financial market information between the insiders and outsiders. And especially in the section of determining the 
criminal liability of the accused insider trading, it should not be ignored about the extremely high risk nature of the informed trading with the legally insider information that is in the early stage of the development of the related major event. [3]

Put aside the economic rationales, the ultimate moral foundation to accuse insider trading is that the informed person make profits by trading on the basis of insider information which makes the trading without risk or under the environment of extremely low risk. Therefore, if the informed person could face extremely high risk when he or she trades stocks or options on the basis of the prophase information related to a major event of the issuer, this type of informed trading should be considered as over-speculative transaction, or even illegal trading on the level of administrative violation, instead of the crime of insider trading. The reason why special emphasis should be laid on the risk of trading the securities on the basis of the preliminary information related to the issuer is because the uncertainty of the informed trading is clear when directional variation of the securities price cannot be estimated at that time.

It may be reasonable to impose the civil or administrative liability of insider trading on the suspected transactions based on the prophase information related to the major events of the securities issuer. Because it not only combines the reality of the capital market that transactions respond to new information in advance of the fact, but compress the trading hours of the insiders, thereby increasing the potential costs of insider trading during the period when the legal nature of the nonpublic information may be blur. However, when it comes to the criminal liability of insider trading, it is necessary to open a window for the prosecutor and defendant to argue whether the actor of the informed trading should be excused based on the conclusion that he or she trades on the basis of the information with high risk.

\section{The Optimization OF THE LegAl Rules ON ANTI-INSIDER TRADING}

Rethinking the practical obstacles and flaws of the legal rules concerning insider trading in China, with the theory and practice support from the US insider trading legislation and judicial rules, provides beneficial references to the financial regulation on insider trading for the Chinese capital market.[4] In my opinion the complexities such as the subject of insider trading, demonstration and defense of trading on the basis of insider information, and determination of materiality, should be analyzed and the relevant legal rules need to be optimized.

\section{A. The Subject of Insider Trading}

According to Article 180 of Criminal Code and Article 74 of Securities Law, the informed persons with insider information, such as the directors, supervisors, senior managers and staffs who have access to the insider information of the company, the majority shareholders or controllers of the company, and the persons who have the access to insider information when they provide financial or legal services for the company, actually all have fiduciary duties to the companies or shareholders. The fundamental reason why these particular types of subject should be banned from insider trading is the fiduciary relationship between them and the company.

Therefore owning fiduciary duty to the company, to some extent consistent with the classic theory, should be the major material characteristics of the informed persons with insider information in the Chinese insider trading law. Besides the regulators and their agents who manage the relevant securities issuing and trading certainly should be banned from insider trading on the basis of the honesty of their public position and the trust they own to the people who delegate the administrative power to them.

Since the material characteristic of the securities insider is that he or she owns fiduciary duty or trust to the issuer or public, the "other persons specified by the State Council's securities regulatory authority" prescribed by Article 74 of Securities Law can be interpreted to any person who have access to the insider information (1) by virtue of his fiduciary duty to the company, such as the position of the administrative, management or supervisory bodies of the company, the holding in the capital of the company, and employment or professional duties in the company; or (2) by virtue of his trust to the public, such as the administrative power to regulate or manage the securities issuing or trading.

\section{B. Defense of Legitimate Transaction}

The core defense of legitimate trading in Chinese insider trading law, the transaction plan, is a simplified edition of the “Safe Harbor" provided by SEC Rule 10b5-1 Trading Plans. Besides Rule 10b5-1 created an affirmative defense especially for the entity which Insider Trading Interpretation did not, there lacks of complementary rules which can make the defense of transaction plans impossible to be applied in the Chinese practice. Therefore a more detailed vision of SEC Rule 10b5-1 Trading Plans should be analyzed for the purpose of being referenced and supplemented by Chinese law.

Insider Trading Interpretation just provided the transaction plans defense in principle but failed to direct the practitioners in the insider trading cases how to operate this safe harbor. Furthermore there have never been any provisions and regulations about the applicability and procedure of the transaction plans in Chinese Securities Law. Therefore the securities and futures market laws and regulations should define the transaction plans which can acquit the person from insider trading when he or she trades while in possession of material nonpublic information. The following legal elements may be fulfilled to sustain the defense of transaction plans: (1) The time of the transaction plan. The transaction plan must be formulated before the accused possess the insider information. (2) The factors of the transaction plan. The core factors of the trading plan must fulfill the minimum requirement. The plan should specify the amount of securities to be purchased or sold and the price and date on which the securities were to be purchased or sold. ${ }^{1}$ (3) The consistence between the plan and the implementation. The purchase or sale at issue must occur pursuant to the contract, order or plan. The trading plan may

\footnotetext{
${ }^{1} 17$ C.F.R. § 240.10b5-1(c)(1)(iii) provides the reference about how to define the amount, price and date of the transaction.
} 
be modified at any time provided that the defendant has not possessed insider information. But the person into the trading plan cannot deviate from the plan, or make a corresponding or hedging transaction with the essence of modifying the planed securities or futures transactions. According to an empirical study in US,[5] statistics showed that executives selling shares through 10b5-1 plans do substantially better than would be expected if trading were truly automatic: in a calculation of roughly 117,000 trades made by 3,426 executives at 1,241 companies, trades made inside plans beat the market by $6 \%$ over six months, while those at the same firms who traded outside of plans only topped it by $1.9 \%$. The study also observed that insiders' sales participating in preplanned transaction systematically follow positive and precede negative firm performance, generating abnormal forwardlooking returns larger than those earned by non-participating colleagues. 2 Therefore the abuse of prearranged transaction plans could be an explanation the apparent disparity in trading profits. Despite there is no relevant empirical research results or regulatory report on the problem of transaction plan abuse in China, the regulatory agency and the judicial department should enhance the standard of examination on the operation and defense of preplanned transactions, especially focusing on those cases which the insiders make plans in advance of bad news becoming public, terminate plans before financial instrument prices decrease, or manipulate content or timing of material disclosures after transactions had been instructed.

\section{Determination of Materiality in the Session of $M \& A$}

Materiality must be determined on a case-to-case basis according to the fact pattern of each specific transaction. ${ }^{3}$ This judgment soundly underlines the significance to consider the facts related to materiality in each insider trading case. But it is not impossible to conclude some core judicial rules on materiality addressing certain specific type of insider information. As a matter of fact, it is absolutely practicable to interpret the regular patterns of the generation of insider information on the typical occasions, such as M\&A, financial situation, and major commercial contracts, in marketplace.

M\&A are heavily affected by egregious insider information transmission. For the Chinese capital market, since the reform of non-tradable shares that have eventually achieved full circulation, there has been an increasing number of M\&A and financial restructuring activities and also a growing number of insider trading cases. From 2008 to 2011, insider trading cases investigated by the CSRC respectively accounted for $38 \%, 56 \%, 71 \%$ and $61 \%$ of the total cases which were informally investigated, 32\%, 24\%, 51\% and 51\% of the total cases which were formally investigated, and $15 \%$, $42 \%, 50 \%$ and $80 \%$ of cases referred to public security authorities. ${ }^{4}$ The noticeable rise in the percentage of insider trading cases in the total cases and the increasing number of mergers and acquisitions and financial restructuring activities are definitely correlated. M\&A and restructuring of listed

\footnotetext{
${ }^{2}$ Alan D. Jagolinzer, SEC Rule 10b5-1 and Insiders' Strategic Trade, 55 Mgmt. Sci. 224 (2009).

${ }^{3}$ Radiation Dynamics, Inc v. Goldmuntz, 464 F.2d 876, 888 (2d Cir 1972).

${ }^{4}$ Zhifeng Xu, Insider Trading Shakes the Foundation of China's Securities Market, People's Daily (May 25, 2012) 10.
}

companies are heavily affected by insider trading. Nearly half of insider trading cases investigated and prosecuted by the CSRC are related to $\mathrm{M} \& \mathrm{~A}$ and restructuring. ${ }^{5}$

Information concerning M\&A is considered quintessentially material by the US federal courts, ${ }_{7}^{6}$ especially the purchasing company try to keep confidential. ${ }^{7}$ And there are mature rules to determine materiality of information on M\&A in US. But the judicial rules related to materiality in Chinese courts have not been seriously analyzed for the purpose of developing a typed rule for this complexity. In my opinion it is necessary to selectively analyze the regular pattern and case experiences of materiality of nonpublic information on M\&A and restructuring and design typed rules for the judicial determination, on which other types of insider information related to major contracts, finance expectation, management variation, etc., could be developed progressively.

Basically the court found materiality of the nonpublic information on the parties of the M\&A dealing were in the place to negotiate in China's criminal insider trading cases: (1) In the "Yanbian Highway Case", the information was considered material when Guangfa Securities had made a back-door listing memorandum about choosing Liaoning Times or Yanbian High way as the alternative acquired firms. (2) In the "Tianshan Textile Case", the information on the outline about the recombinant of Katie Investment and Tianshan Textile planed by the government of the Xinjiang Uygur Autonomous Region, State-owned Assets Supervision and Administration Commission of Xinjiang Uygur Autonomous Region and Kaitie Investment was found material. (3) In the "Gaochun Ceramics Case”, it was considered material when for the first time in written form the fourteenth China Electronics Technology Group Institute was chosen as the purchasing entity of the upcoming restructuring. ${ }^{9}$ (4) In the "Shanghai Zulong Case", both of the potential dealing parties of M\&A were controlled by Rongsheng Chen, therefore, the information on Chen meeting with financial consultants of the

\footnotetext{
${ }^{5}$ Xiaobo Zheng \& Lu Liu, The Momentum of Insider Trading Suppressed to Some Extent, Sec. Times (Apr. 6, 2011) A1.

${ }^{6}$ SEC v. Svoboda, 409 F.Supp.2d 331 (S.D. N.Y. 2006); SEC v. Gonzalez de Castilla, 145 F. Supp. 2d 402 (S.D. N.Y. 2001).

${ }^{7}$ SEC v. Suman, 684 F. Supp. 2d 378 (S.D. N.Y. 2010).

${ }^{8}$ In 2009, the govemment of the Xinjiang Uygur Autonomous Region for the promotion of the listed company, Tianshan Textile, forced advancing its restructuring. On July 20, 2009, the govemment of the autonomous region conferences identified the recombinant of Katie Investment and Tianshan Textile. Rongjiang Yao, the general manager of Kaitie Investment and foreign investment company deputy general manager Ge Cao, discussed specific content of the reorganization plan after programming. On July 22nd, the related leadership of the govemment of the autonomous region of agreed with the proposal. On July 23rd, Tianshan Textile stock was suspended until June 18 of 2010, the stock resumed trading after the consecutive number of trading. CSRC confirmed that the reorganization matters belonged to inside information. July 21st moming, Rongjiang Yao told Qing Wang, legal representative of the Xinjiang Sun Investment Company, about the information of the reorganization through the mobile phone. Qing Wang bought total 1,285,000 shares of Tianshan Textile on July 21st and 22nd through online trading. The CSRC initiated the investigation and transferred the case to the Ministry of Public Security in July 2010. Relevant criminal suspects, including Rongjiang Yao were taken into custody, arrested and released on bail. In December 2010, Rongjiang Yao was convicted of the crime of insider trading and leaking insider information, sentenced to three years imprisonment with four years suspention, and imposed a fine of 3 million yuan. See Zheling Zhou, The Details of Tianshan Textile Insider Trading Case Exposed, China Sec. J. (Jan. 18, 2011) 8.

${ }^{9}$ Su Jiang, The Truth behind Gaochun Ceramics, 21st Cen. Econ. Rep. (Jan. 15, 2011)13.
} 
investment bank and the senior managers of the listed company, Creative Technology, to discussing the Asset injections was material. ${ }^{10}$ (5) In the "Zhongshan Public Utilities Case”, Zhongshan Public Utilities Group Company, a state-owned company and the controlling shareholder of the listed company, Zhongshan Public Utilities Technology Stock Company, decided to inject Croup Company's assets into the listed company for the purpose of overall listing. The information on the chairman of the board of the Croup Company reporting to Kaigen Chen, the former secretary of the Communist Party Committee of Zhongshan Municipal City, about the program of assets injection, was material, since the major assets disposal should be approved by the government. ${ }^{11}$ Evidently in Chinese insider trading judicial practice, materiality of the nonpublic information in the session of M\&A can be located at the stage when the parties of the equity transaction are emplaced. This typed rule can be integrated into the system of judicial determination of materiality.

\section{CONCLUSION}

The Chinese capital market directly confronts the competition from the developed and emerging financial markets in the wake of China's economy becoming one of the most important constituent parts of the world economy. It challenges China's financial market to enhance the international competitiveness. The reformation and development of China's capital market needs to strengthen the legal rules, accelerate the process of constructing and improving the financial laws and regulatory institutions, therefore, the actual strength of international financial competition will be consolidated. Nevertheless, considering the existing situation of rule of law in China's capital market, the financial legal system, especially the insider trading law, finds it difficult to meet the challenge of insider trading in the process of financial system reformation and financial innovation. China has made significant achievements in the regards of exploration of regulatory enforcement, and technical innovation of legislation, however, it is necessary to face and recognize this problem soberly, that the existing regulatory framework cannot solve most of the complexities brought about by insider trading. Learning form the American experiences can provide beneficial references to the enforcement practice against insider trading.

For the optimization and reformation of the legal rules against insider trading, [6] Chinese insider trading law should be improved in the following way: A systematic mechanism of private action of insider trading cases should be constructed in China, especially the right of initiating class action, which will give the real protection to the investors who may be harmed by insider trading. The civil, administrative and criminal liability of insider trading should be estimated on the basis of the risk the informed person undertakes during the scheme of

\footnotetext{
${ }^{10}$ Lei Lv, Experts Analyzed the Boundary of the Crime of Insider Trading, Shanghai L. Daily (Jul. 9, 2010) A8.

${ }^{11}$ Jianping Huang \& Mei Liang, The Insider Trading Criminal Case of Qihong $\mathrm{Li}$, in REFERENCE TO CRIMINAL TRIAL, edited by THE CRIMINAL TRIBUNAL NO.1 TO NO.5 AT THE PEOPLE'S SUPREME COURT OF THE PEOPLE'S REPUBLIC OF CHINA (Law Press China 2012) 2.
}

insider trading. Owning fiduciary duty to the company, to some extent consistent with the classic theory, should be the major material characteristics of the informed persons with insider information in the Chinese insider trading law. A more detailed vision of SEC Rule 10b5-1 Trading Plans should be integrated into Chinese insider trading law. Specific clarifications and typed judicial rules should be made on determination of materiality of insider information on $M \& A$, because M\&A are heavily affected by egregious insider information transmission in China.

\section{REFERENCES}

[1] Huang, Hui, 2005. The regulation of insider trading in China: a critical review and proposals for reform. Aust. J. Corp L. 17 (3), 281-322.

[2] Cumming, Douglas, Johan, Sofia, Li, DAN, 2011. EXCHANGE TRADING RULES AND STOCK MARKET LIQUIDITY. J. FINAN. ECON. 99, 651-671.

[3] Howson, NiCHOLAS C., 2012. ENFORCEMENT WITHOUT FOUNDATION? E INSIDER TRADING AND CHINA'S ADMINISTRATIVE LAW CRISIS. AM. J. COMP. L. 60, 955-1002.

[4] Keith, RONALD C., LIN, ZHIQIU, 2009. JUDICIAL INTERPRETATION OF CHINA'S SUPREME PEOPLE'S COURT AS "SECONDARY LAW" WITH SPECIAL REFERENCE TO CRIMINAL LAW. CHINA INFO. 23, 223-255.

[5] JAGOLINZER, ALAN D., 2009. SEC RULE 10B5-1 AND INSIDERS' strategic TRADE. MANAG. SCI. 55, 224-239.

[6] Wei, LI, 1997. JUDICIAL INTERPRETATION IN CHINA. WILLAMETTE J. INT L. DISP. RESOL. 5, 87-112. 